\title{
Nitrogen Management in Organic Processing Tomato Production: Nitrogen Sufficiency Prediction Through Early-season Soil and Plant
Monitoring
}

\author{
S. Castro Bustamante and T.K. Hartz ${ }^{1}$ \\ Department of Plant Sciences, University of California, Davis, CA 95616
}

Additional index words. fertilization, nitrogen deficiency, sensitivity analysis, Solanum lycopersicum

\begin{abstract}
Organic processing tomato (Solanum lycopersicum L.) production is a significant industry in California, yet little nitrogen $(N)$ fertility research is available to guide $\mathbf{N}$ management. A total of 37 certified organic processing tomato fields in the Sacramento Valley of California were monitored during the 2012 and 2013 production seasons, with two objectives: 1) to document current $N$ management practices and 2) to investigate the utility of early-season soil and plant $\mathbf{N}$ monitoring techniques in predicting seasonal crop $\mathrm{N}$ sufficiency. Between $\approx 3$ and 11 weeks after transplanting (WAT) soil mineral $\mathbf{N}$ (SMN), leaf $\mathrm{N}$ and petiole $\mathrm{NO}_{3}-\mathrm{N}$ were determined every other week. In 22 fields, whole plant $N$ concentration at $\approx 11$ WAT was determined as a measure of crop $N$ sufficiency. Growers were surveyed regarding $N$ management practices used and fruit yields achieved. Net $\mathbf{N}$ mineralization $\left(\mathbf{N}_{\min }\right)$ was measured for 20 fields soils by aerobic laboratory incubation. Carbon mineralization $\left(C_{\min }\right)$ in 24 hours following rewetting of air-dried soil and water extractable organic nitrogen (WEON) and carbon (WEOC) were also determined and evaluated as predictors of $\mathbf{N}_{\text {min }}$. Nitrogen management was primarily based on the application of manure or manure compost in the fall. Organic fertilizers were applied mainly in spring (pre- and post-transplanting). SMN in the top $60 \mathrm{~cm}$ at 3 WAT ranged from 6 to $32 \mathrm{mg} \cdot \mathrm{kg}^{-1}$. About $30 \%$ of fields were $\mathrm{N}$ deficient by 11 WAT. Sensitivity analysis showed that SMN (whether measured from 0 to 30 or 0 to $60 \mathrm{~cm}$ ) and leaf $N$ at 5 WAT correctly predicted late-season plant $N$ status in $>60 \%$ of the fields. $N_{\min }$ in 28 days ranged from 8 to $31 \mathrm{mg} \cdot \mathrm{kg}^{-1}$, representing an average of $2 \%$ of total soil $\mathrm{N}$. Correlation between $\mathrm{N}_{\min }$ and $C_{\min }$ was weak $(r=0.44, P=0.051)$ while stronger correlations were observed between $N_{\text {min }}$ and WEOC, WEON and total soil $N$ $(r=0.63,0.61$ and 0.51 , respectively, all $P<0.03)$. A multiple linear regression model that used 3 WAT SMN $(0-30 \mathrm{~cm})$ and WEON as independent variables improved $N_{\min }$ prediction (adj. $\left.R^{2}=0.67\right)$. Significant fruit yield increase with sidedress $\mathrm{N}$ application of feather meal at 5-6 WAT was observed in 2 of 4 field trials, demonstrating the ability to remedy a soil $\mathrm{N}$ limitation identified by early-season $\mathrm{N}$ monitoring.
\end{abstract}

California is a leader in the organic production of processing tomato (Solanum lycopersicum L.), with $>3,400$ ha produced annually (Klonsky, 2010). Nitrogen is often the most limiting nutrient in organic vegetable production systems, especially in high $\mathrm{N}$ demand crops such as tomato (Gaskell and Smith, 2007). Not only must organic soil management provide sufficient plant-available $\mathrm{N}$ to maximize crop productivity, but also do so in a timely manner to ensure that crops are not $\mathrm{N}$ limited at any growth stage. Achieving synchrony between soil $\mathrm{N}$ availability and crop $\mathrm{N}$ demand has been recognized as a central challenge of organic $\mathrm{N}$ management (Berry et al., 2002; Bhogal et al., 2001; Gaskell and Smith, 2007; Gill et al., 1995; Hatch et al., 1991).

Received for publication 9 Apr. 2015. Accepted for publication 5 May 2015.

${ }^{1}$ To whom reprint requests should be addressed; e-mail tkhartz@ucdavis.edu.
Processing tomato has a high $\mathrm{N}$ requirement for peak production. Hartz and Bottoms (2009) reported a mean aboveground biomass $\mathrm{N}$ accumulation of $296 \mathrm{~kg} \cdot \mathrm{ha}^{-1}$ in high yield conventionally farmed fields. Crop $\mathrm{N}$ uptake was slow in the initial month after transplanting, with the rate increasing to $>4$ $\mathrm{kg} \cdot \mathrm{ha}^{-1} \cdot \mathrm{d}^{-1}$ during fruit set and early ripening. This pattern of crop $\mathrm{N}$ uptake highlights the problem of synchronizing $\mathrm{N}$ availability in organic production. The rate of $\mathrm{N}_{\min }$ from cover crops or organic amendments incorporated before planting has been shown to peak before the period of highest crop $\mathrm{N}$ demand (Gaskell and Smith, 2007). This suggests that measuring SMN $\left(\mathrm{NH}_{4}-\mathrm{N}\right.$ and $\left.\mathrm{NO}_{3}-\mathrm{N}\right)$ concentration after transplanting, but before rapid crop $\mathrm{N}$ uptake, might be useful in predicting the $\mathrm{N}$ sufficiency of organic fields (Muramoto et al., 2011). The value of considering residual SMN in determining sidedress $\mathrm{N}$ requirement has been documented in conventional production of many crops
(Breschini and Hartz, 2002; Fox et al., 1989; Hartz et al., 2000; Heckman et al., 1995, 2002; Krusekopf et al., 2002), but the utility of this practice in organic vegetable production has not been widely investigated.

The ability to predict seasonal soil $\mathrm{N}_{\min }$ potential would also be useful to inform in-season $\mathrm{N}$ management. In recent years, several laboratory methods for soil $\mathrm{N}_{\text {min }}$ prediction have been proposed that could be practical for routine agronomic use. Short-term $\mathrm{C}_{\min }$ following rewetting of dry soil has been reported to correlate well with soil $\mathrm{N}_{\text {min }}$, as measured in longer term, aerobic soil incubation (Haney et al., 2001, 2008a, 2008b). The measurement of WEOC and WEON has been reported to be highly correlated with $\mathrm{C}_{\min }$, and this additional information regarding the labile $\mathrm{C}: \mathrm{N}$ ratio may improve soil $\mathrm{N}_{\min }$ prediction (Haney et al., 2012).

Plant tissue analysis has been widely used to document crop $\mathrm{N}$ sufficiency. For tomato, leaf $\mathrm{N}$ and petiole $\mathrm{NO}_{3}-\mathrm{N}$ sufficiency standards are available (Hartz et al., 1998; Jones et al., 1991; Lorenz and Tyler, 1983). Historically, tissue $\mathrm{N}$ analysis has been used as a measure of current sufficiency; it is unclear from existing literature the degree to which tissue analysis can give inference on future $\mathrm{N}$ fertilization requirement.

There is little data available on efficient $\mathrm{N}$ management in organic processing tomato production, or the adequacy of current practices to maximize productivity. Similarly, data are lacking on the effectiveness of soil and tissue $\mathrm{N}$ monitoring in guiding in-season $\mathrm{N}$ management. This study was undertaken with two objectives. First, to document current $\mathrm{N}$ management practices in organic tomato production in the Sacramento Valley of California. Second, to investigate the utility of soil and plant $\mathrm{N}$ monitoring in predicting seasonal crop $\mathrm{N}$ sufficiency, and the need for in-season $\mathrm{N}$ fertilization.

\section{Materials and Methods}

Field monitoring. A total of 37 certified organic processing tomato fields were monitored during the 2012 and 2013 productions seasons, 10 fields in 2012, and 27 fields in 2013. All fields were located in the Sacramento Valley of California (about lat. $38^{\circ} 50^{\prime} \mathrm{N}$, long. $121^{\circ} 50^{\prime} \mathrm{W}$ ). Fields were transplanted between 3 Apr. and 1 May in 2012 and between 18 Mar. and 10 May in 2013; a total of 13 hybrid, determinate processing cultivars were used. The planting configuration was $1.5-\mathrm{m}$ wide soil beds, with either one or two rows of plants per bed. Plant population ranged from $\approx 16,000$ to 20,000 plants/ha. All fields were furrow irrigated except field 19, which was drip irrigated. Information regarding all fertilityrelated practices (cover cropping, organic fertilizer, and amendment applications) and data on the marketable yields achieved were obtained from the cooperating growers records. 
Soil samples (top $30 \mathrm{~cm}$ ) were collected in all fields at 2-week intervals from $\approx 3$ to 11 WAT; each sample was composed of at least 12 soil cores $(2.5 \mathrm{~cm}$ diameter) representing each of two locations within the bed (in the plant rows, and midway between the plant row and the edge of the bed). These soil cores were collected in a " $X$ " pattern throughout the field to encompass field variability, and were composited to form a single sample per field for each collection date. At the first sampling date in each field soil samples from 30 to $60 \mathrm{~cm}$ depth were also collected in the same manner. Soil mineral $\mathrm{N}$ was determined in $2 \mathrm{~N} \mathrm{KCl}$ extracts of field-moist soil by the spectrophotometric methods of Doane and Horwath $\left(2003\right.$, for $\left.\mathrm{NO}_{3}-\mathrm{N}\right)$ and Forster (1995, for $\mathrm{NH}_{4}-\mathrm{N}$ ).

Additional analyses were conducted on the initial $0-30 \mathrm{~cm}$ sample collected from each field. Soil texture was quantified by the hydrometer method by Sheldrick and Wang (1993). Phosphorus availability was estimated by the bicarbonate extraction method by Olsen and Sommers (1982). Soil organic matter (SOM) was estimated by the procedure by Storer (1984). Total soil N and C were determined by combustion using an
Elemental Combustion System 4010 (Costech Analytical Technologies Inc., Valencia, CA).

About 36 recently mature leaves were collected on each soil sampling date. On half of these leaves the petioles were detached from leaf blades. Whole leaf and petiole samples were oven-dried at $65^{\circ} \mathrm{C}$ to constant mass and ground to pass a $0.4 \mathrm{~mm}$ mesh. Whole leaf $\mathrm{N}$ concentration was determined by the same procedure as for total soil $\mathrm{N}$. Petiole $\mathrm{NO}_{3}-\mathrm{N}$ was determined spectrophotometrically (Doane and Horwath, 2003) after extraction with $2 \%$ acetic acid.

Overall, crop $\mathrm{N}$ status was evaluated in 22 of the 37 fields at $\approx 11$ WAT by determining whole plant $\mathrm{N}$ concentration, and comparing it to the critical $\mathrm{N}$ concentration for processing tomato $\left(\mathrm{N}_{\mathrm{c}}\right.$, the minimum whole plant $\mathrm{N}$ concentration required to maximize growth) developed by Tei et al. (2002) and confirmed for California conditions by Hartz and Bottoms (2009). In each of these fields, which were at the early red fruit growth stage, aboveground plant biomass was estimated by collecting all plant tissue in six representative $60 \mathrm{~cm}$ sections of soil bed. Each sample was divided into vegetative material and fruit, and the fresh weight of each was recorded. Subsamples of both tissue types were prepared by randomly selecting $10-15$ fruit, or $0.5-1.0 \mathrm{~kg}$ of intact braches of vine (stems and leaves). These subsamples were oven dried at $65^{\circ} \mathrm{C}$, reweighed and total crop dry biomass was calculated. Dry tissue was ground to pass a $0.4 \mathrm{~mm}$ mesh (Thomas Wiley ${ }^{\circledR}$ Mini-Mill, Swedesboro, NJ) and the $\mathrm{N}$ concentration of both tissue types was determined as previously described for leaf tissue. Aboveground biomass $\mathrm{N}$ and whole plant $\mathrm{N}$ concentration were calculated.

To adjust for the effects of season and planting date on the rate of crop development cumulative growing degree days (GDD) from the date of transplanting were calculated based on air temperature data obtained from the California Irrigation Management Information System [CIMIS, Pruitt et al., 1987, stations \#6 (Davis), 32 (Colusa), 139 (Winters), and 226 (Woodland)]. Fields were generally within $10 \mathrm{~km}$ of the monitoring station. Daily GDD was calculated using a single sine method (Allen, 1976) with upper and lower thresholds temperature of 30 and $10{ }^{\circ} \mathrm{C}$, respectively. For phenological reference, 300, 600, and 900 GDD roughly

Table 1. Soil characteristics, nitrogen management practices and marketable (Mkt.) yield for 37 organic processing tomato fields.

\begin{tabular}{|c|c|c|c|c|c|c|c|c|c|c|c|}
\hline \multirow[b]{3}{*}{ Season } & \multirow[b]{3}{*}{ Field } & \multirow[b]{3}{*}{ Soil texture ${ }^{y}$} & \multirow[b]{3}{*}{$\mathrm{pH}^{\mathrm{y}}$} & \multirow{3}{*}{$\begin{array}{c}\text { Organic } \\
\text { matter }\left(\mathrm{g} \cdot \mathrm{kg}^{-1}\right)^{\mathrm{y}}\end{array}$} & \multirow{3}{*}{$\begin{array}{c}\text { Olsen P } \\
\left(\mathrm{mg} \cdot \mathrm{kg}^{-1}\right)^{\mathrm{y}}\end{array}$} & \multirow{2}{*}{\multicolumn{2}{|c|}{ Soil mineral $\mathrm{N}\left(\mathrm{mg} \cdot \mathrm{kg}^{-1}\right)^{\mathrm{y}}$}} & \multicolumn{3}{|c|}{$\mathrm{N}$ application ${ }^{\mathrm{z}}$} & \multirow{3}{*}{$\begin{array}{c}\text { Mkt. }^{\mathrm{x}} \text { yield } \\
\left(\mathrm{t} \cdot \mathrm{ha}^{-1}\right)\end{array}$} \\
\hline & & & & & & & & & Spring & & \\
\hline & & & & & & $0-30 \mathrm{~cm}$ & $0-60 \mathrm{~cm}$ & Fall & pretransplant & Post-transplant & \\
\hline 2012 & 1 & Clay loam & 6.4 & 27 & 53 & 27 & 24 & $\mathrm{MC}$ & $\mathrm{C}, \mathrm{F}$ & - & 91 \\
\hline 2012 & 2 & Loam & 6.1 & 22 & 56 & 43 & 32 & $\mathrm{MC}$ & $\mathrm{F}$ & - & 74 \\
\hline 2012 & 3 & Clay loam & 6.3 & 28 & 65 & 43 & 29 & & $\mathrm{~F}$ & - & 78 \\
\hline 2012 & 4 & Clay loam & 7.1 & 27 & 54 & 8 & 8 & $\mathrm{~F}$ & & - & 56 \\
\hline 2012 & 5 & Clay loam & 7.7 & 24 & 50 & 10 & 10 & - & $\mathrm{F}$ & - & 44 \\
\hline 2012 & 6 & Clay loam & 6.5 & 25 & 83 & 21 & 24 & M & - & - & 91 \\
\hline 2012 & 7 & Clay & 6.5 & 26 & 98 & 18 & 22 & M & - & - & 91 \\
\hline 2012 & 8 & Clay & 6.6 & 24 & 75 & 23 & 27 & M & - & - & 87 \\
\hline 2012 & 9 & Silty clay & 7.1 & 28 & 62 & 16 & 15 & M & $\mathrm{F}$ & $\mathrm{F}$ & 113 \\
\hline 2012 & 10 & Silty clay & 6.7 & 21 & 59 & 8 & 6 & $\mathrm{C}$ & - & $\mathrm{F}$ & 74 \\
\hline 2013 & 11 & Clay & 7.1 & 27 & 11 & 13 & 9 & - & $\mathrm{C}$ & - & 41 \\
\hline 2013 & 12 & Silty clay & 7 & 23 & 6 & 10 & 7 & - & $\mathrm{C}$ & $\mathrm{F}$ & 58 \\
\hline 2013 & 13 & Clay & 7.5 & 30 & 4 & 20 & 14 & M & - & - & 49 \\
\hline 2013 & 14 & Clay & 7.5 & 24 & 5 & 25 & 16 & M & $\mathrm{F}$ & - & 38 \\
\hline 2013 & 15 & Clay loam & 7.1 & 22 & 12 & 26 & 19 & $\mathrm{~F}$ & $\mathrm{~F}$ & - & 56 \\
\hline 2013 & 16 & Clay & 6.4 & 30 & 28 & 14 & 15 & $\mathrm{MC}$ & $\mathrm{F}$ & $\mathrm{F}$ & 71 \\
\hline 2013 & 17 & Clay & 6.7 & 28 & 25 & 14 & 17 & $\mathrm{MC}$ & $\mathrm{F}$ & - & 76 \\
\hline 2013 & 18 & Silty clay loam & 7.1 & 22 & 18 & 6 & 13 & $\mathrm{MC}$ & $\mathrm{F}$ & - & 96 \\
\hline 2013 & 19 & Clay loam & 7 & 29 & 25 & 18 & 14 & $\mathrm{MC}$ & $\mathrm{F}$ & - & 83 \\
\hline 2013 & 20 & Loam & 6.7 & 13 & 15 & 17 & 19 & $\mathrm{MC}$ & $\mathrm{F}$ & - & 106 \\
\hline 2013 & 21 & Silty clay & 6.7 & 18 & 72 & 20 & 17 & $\mathrm{M}$ & - & - & 108 \\
\hline 2013 & 22 & Silty clay & 6.7 & 18 & 61 & 22 & 17 & M & - & - & 106 \\
\hline 2013 & 23 & Clay loam & 7.1 & 19 & 57 & 24 & 21 & M & - & - & 107 \\
\hline 2013 & 24 & Clay loam & 6.6 & 19 & 38 & 22 & 18 & M & & - & 110 \\
\hline 2013 & 25 & Silty clay & 6.9 & 20 & 67 & 23 & 17 & M & - & - & 110 \\
\hline 2013 & 26 & Clay & 6.1 & 14 & 39 & 10 & 7 & M & - & $\mathrm{F}$ & 108 \\
\hline 2013 & 27 & Silty clay & 6.6 & 20 & 34 & 25 & 17 & M & - & - & 102 \\
\hline 2013 & 28 & Clay loam & 7.1 & 19 & 65 & 25 & 23 & M & - & - & 94 \\
\hline 2013 & 29 & Clay & 6.7 & 21 & 51 & 26 & 20 & M & - & - & 110 \\
\hline 2013 & 30 & Clay & 6.6 & 18 & 35 & 25 & 19 & M & - & - & 89 \\
\hline 2013 & 31 & Clay loam & 6.4 & 17 & 33 & 23 & 19 & M & - & - & 103 \\
\hline 2013 & 32 & Silty clay & 7.5 & 27 & 11 & 16 & 14 & - & - & $\mathrm{F}$ & 115 \\
\hline 2013 & 33 & Silty clay & 7.3 & 25 & 27 & 11 & 9 & - & - & $\mathrm{F}$ & 81 \\
\hline 2013 & 34 & Silty clay loam & 7.0 & 23 & 15 & 23 & 18 & M & $\mathrm{F}$ & $\mathrm{F}$ & 101 \\
\hline 2013 & 35 & Silty clay loam & 7.1 & 23 & 26 & 22 & 16 & M & $\mathrm{F}$ & $\mathrm{F}$ & 116 \\
\hline 2013 & 36 & Sandy clay loam & 6.5 & 16 & 10 & 12 & 11 & $\mathrm{C}$ & - & $\mathrm{F}$ & 86 \\
\hline 2013 & 37 & Clay loam & 7.3 & 17 & 13 & 12 & 8 & $\mathrm{C}$ & - & $\mathrm{F}$ & 71 \\
\hline
\end{tabular}

${ }^{\mathrm{z}} \mathrm{M}=$ manure, $\mathrm{MC}=$ manure compost, $\mathrm{C}=$ compost, $\mathrm{F}=$ organic fertilizer.

${ }^{\mathrm{y}}$ Measurement performed on the first date soil sample in each field.

${ }^{\mathrm{x}}$ Marketable (intact red fruit). 
corresponded to early bloom, full bloom, and early red fruit growth stages.

Sidedress $N$ trials. Four field trials were conducted in 2013 to evaluate crop response to sidedress $\mathrm{N}$ application. These trials were conducted in fields 12,16 , and 18 , and in an organically managed processing tomato field at the UC Russell Ranch (RR) Sustainable Agriculture facility near Winters, CA. The cultivars planted were Nunhems 6404 (fields 12 and 18), Seminis 4606 (field 16), and Seminis AB2 (RR). All fields were furrow irrigated. Transplanting occurred on $13 \mathrm{Apr}$. (field 12), 21 Mar. (field 16), 21 Mar. (field 18), and 17 Apr. (RR). Each trial was conducted using a randomized complete block experimental design with six replications. Experimental units were three $1.5 \mathrm{~m}$ beds wide by $30 \mathrm{~m}$ long in the commercial fields, and $23 \mathrm{~m}$ long at RR. The treatments compared were in-season $\mathrm{N}$ sidedressing, and no in-season $\mathrm{N}$ application. All data were collected from the middle bed of each plot.

Fields 16 and 18 were sidedressed on 3 May with a feather meal-based fertilizer $(12 \mathrm{~N}-1.3 \mathrm{P}-0 \mathrm{~K})$ at a rate of $30 \mathrm{~kg} \cdot \mathrm{ha}^{-1} \mathrm{~N}$. Field 12 was sidedressed 15 May with feather meal $(12 \mathrm{~N}-0 \mathrm{P}-0 \mathrm{~K})$ at $34 \mathrm{~kg} \cdot \mathrm{ha}^{-1} \mathrm{~N}$. The RR trial was sidedressed on 20 May using a feather meal-based fertilizer $(12 \mathrm{~N}-1.3 \mathrm{P}-$ $0 \mathrm{~K}$ ) at a rate of $35 \mathrm{~kg} \cdot \mathrm{ha}^{-1} \mathrm{~N}$. Immediately before the sidedress $\mathrm{N}$ application 8 soil cores were collected from 0 to 30 and 30 to $60 \mathrm{~cm}$ deep in each block at all trial sites. Recently mature whole leaves were collected concurrently with soil sampling. About 4 weeks after $\mathrm{N}$ sidedressing leaf and petiole samples were again collected in each replicate plot of both treatments. SMN, leaf N, and petiole $\mathrm{NO}_{3}-\mathrm{N}$ were determined as previously described.

In the commercial fields, fruit yields were determined several days before the growers' once over, mechanical harvest by manually harvesting all fruit in a $5 \mathrm{~m}$ section in each plot. At RR, a mechanical harvest was done in a $15 \mathrm{~m}$ section of each plot. In all fields, an $18 \mathrm{~L}$ sample of randomly selected fruit from each plot was collected for quality determination. Fruit were graded to separate intact, marketable red fruit from cull fruit (green, rot, and sunburn); fruit size was not evaluated as it is not an important quality parameter for processing tomatoes. A total of $4 \mathrm{~kg}$ samples of marketable fruit were transported to the Processing Tomato Advisory Board inspection station in Dixon, CA. There the fruit were mechanically juiced and soluble solids' concentration were measured by refractometer according to the standard industry protocol.

Soil $N_{\min }$ potential. Additional analyses were performed on the first soil samples ( 0 $30 \mathrm{~cm}$ depth) collected in 20 of the 37 monitored fields (10 from 2012 and 10 from 2013) to evaluate net $\mathrm{N}_{\min }$ potential. Soils were air-dried and sieved through $2 \mathrm{~mm}$ mesh, then analyzed for SMN as previously outlined. $\mathrm{N}_{\min }$ was determined by aerobic incubation at constant moisture and temperature. In 2012, this was accomplished by placing $40 \mathrm{~g}$ of dry soil in $50 \mathrm{~mL}$ beakers and wetting to $50 \%$ water-filled pore space (WFPS), as estimated by the method of Haney and Haney (2010). Three replicate beakers of each field soil were incubated in sealed $300 \mathrm{~mL}$ glass jars at $25^{\circ} \mathrm{C}$ for $28 \mathrm{~d}$; the jars were vented after $7 \mathrm{~d}$ to maintain aerobic conditions. After $28 \mathrm{~d}$ the soil samples were extracted in $2 \mathrm{~N} \mathrm{KCl}$ and SMN was determined. Nitrogen mineralization was calculated as the increase in mineral $\mathrm{N}$ over the incubation period. In 2013 the incubation assay was performed with $14 \mathrm{~g}$ samples of dry soil placed in $50 \mathrm{~mL}$ centrifuge tubes. Soils were wetted to $50 \%$ WFPS, and incubated at $25{ }^{\circ} \mathrm{C}$ in sealed $1 \mathrm{~L}$ glass jars, 4 tubes per jar. After 7, 28, 42, and $70 \mathrm{~d}$ four replicate tubes of each soil were extracted with $40 \mathrm{~mL} 2 \mathrm{~N} \mathrm{KCl}$ for determination of mineral $\mathrm{N}$, as previously described.

Three additional laboratory soil analyses were conducted. $\mathrm{C}_{\min }$ in $24 \mathrm{~h}$ following rewetting of air-dried soil was determined by a proprietary procedure, the Solvita ${ }^{\circledR}$ test

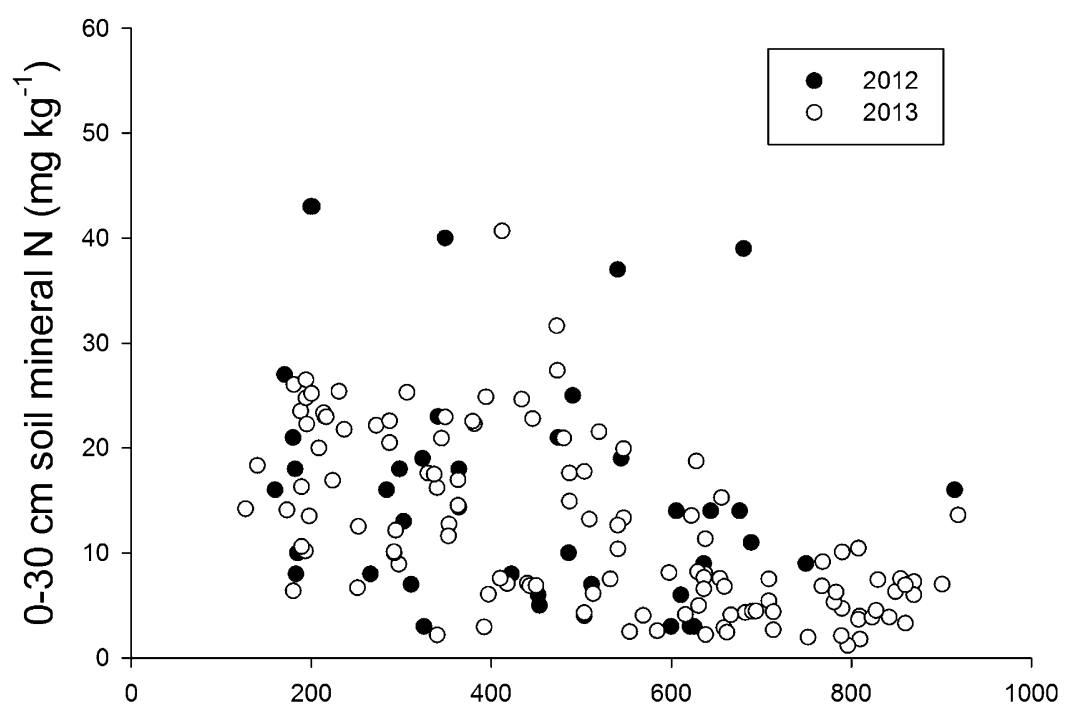

Cumulative growing degree days since transplanting $\left({ }^{\circ} \mathrm{C}\right)$

Fig. 1. Trends in soil mineral N (0-30 cm depth) in 37 fields produced during the $2012(\bullet)$ and $2013(\bigcirc)$ growing seasons; 300, 600 and 900 growing degree days corresponded to early bloom, full bloom and early red fruit growth stages.

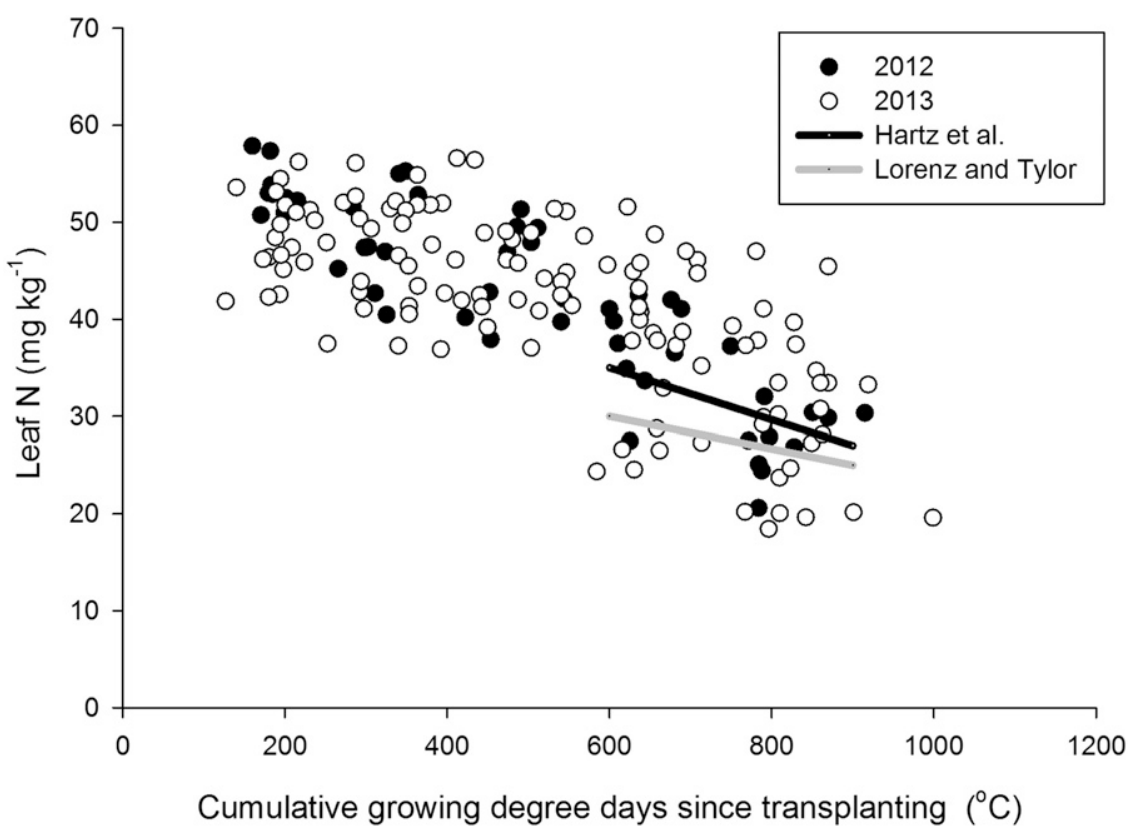

Fig. 2. Trends in leaf $\mathrm{N}$ concentration in 37 fields produced during the $2012(\bullet)$ and $2013(\bigcirc)$ growing seasons; 300, 600, and 900 growing degree days corresponded to early bloom, full bloom and early red fruit growth stages. N sufficiency standards proposed by Hartz et al. (1998; black line) and Lorenz and Tyler (1983; gray line). 
(Haney et al., 2008a, 2008b). $\mathrm{C}_{\min }$ analysis was performed on triplicate samples of each field soil. Water-extractable organic $\mathrm{C}$ and $\mathrm{N}$ (WEOC, WEON) were measured by the procedure of Haney et al. (2012). WEOC and WEON were measured on duplicate samples of each field soil.

Statistical analysis. Correlation and regression analyses were performed using SigmaStat imbedded in SigmaPlot version 11 (Systat Sofware, Inc., San Jose, CA). N sidedressing effects on plant $\mathrm{N}$ status and fruit yield were evaluated using the GLM procedure and Tukey's Studentized range test provided by the SAS statistical package (SAS Institute, Cary, NC, version 9.3). Sensitivity analysis (Pannell, 1997) was performed to assess the ability to predict the development of late-season crop $\mathrm{N}$ deficiency from earlyseason soil and plant monitoring.

\section{Results}

Field monitoring. Field soils ranged in texture from loam to clay, and $\mathrm{pH}$ from 6.1 to 7.7 (Table 1). Soil organic matter varied from 13 to $30 \mathrm{~g} \cdot \mathrm{kg}^{-1}$. Soil mineral $\mathrm{N}$ at $3 \mathrm{WAT}$ ranged from 6 to $43 \mathrm{mg} \cdot \mathrm{kg}^{-1}$ (top $30 \mathrm{~cm}$ ) and 6 to $32 \mathrm{mg} \cdot \mathrm{kg}^{-1}(0-60 \mathrm{~cm})$, with $>90 \%$ in $\mathrm{NO}_{3}-\mathrm{N}$ form in all fields. Large differences in bicarbonate extractable (Olsen) soil P (4-98 $\mathrm{mg} \cdot \mathrm{kg}^{-1}$ ) were also observed.

Substantial differences in fertility management were apparent in the grower-reported practices. Most fields received a fall application of manure or manure compost (Table 1). Three fields received a spring, pretransplanting application of compost, whereas in 14 fields an organic fertilizer (typically a high-N content material such as feather meal) was applied before transplanting. A post-transplanting application of fertilizer was made in 11 fields, with common materials being feather meal and Chilean nitrate $\left(\mathrm{NaNO}_{3}\right)$. Pre- and post-transplanting fertilization was typically limited to $<35 \mathrm{~kg} \cdot \mathrm{ha}^{-1} \mathrm{~N}$. Field 10 was the only field in which a winter cover crop was grown preceding tomato planting. Marketable fruit yield varied from 38 to $116 \mathrm{t} \cdot \mathrm{ha}^{-1}$, averaging $86 \mathrm{t} \cdot \mathrm{ha}^{-1}$; for context, mean fruit yield in conventionally grown Sacramento Valley fields in these years was $\approx 105 \mathrm{t} \cdot \mathrm{ha}^{-1}$.

Across years, SMN declined as the season progressed [Fig. 1; $\ln (\mathrm{SMN})=3.285-$ $(0.00197 \times$ GDD $), r=0.55, P<0.001]$. By the full bloom growth stage (roughly 9 WAT), most fields had $<10 \mathrm{mg} \cdot \mathrm{kg}^{-1} \mathrm{SMN}$. At the last sample date (which roughly corresponded to the early red fruit growth stage), SMN in many fields was $<5 \mathrm{mg} \cdot \mathrm{kg}^{-1}$.

Leaf $\mathrm{N}$ concentration also declined as the season progressed in both years [Fig. 2; Leaf $\mathrm{N}=57.78-(0.0313 \times \mathrm{GDD}), r=0.75, P<$ $0.001]$. In 16 fields, the last sample showed leaf $\mathrm{N}$ below the sufficiency level proposed by Hartz et al. (1998); in only 11 fields was the last leaf sample below the sufficiency guidelines of Lorenz and Tyler (1983). Both reference standards were based on determinate, processing cultivars grown in California. It should be noted that the sufficiency guidelines of Hartz et al. (1998) were developed from an industry survey of conventional fields, and were acknowledged to likely be higher than actually required for optimum growth. By the last sampling date, leaf $\mathrm{N}$ varied from $<20$ to $>40 \mathrm{~g} \cdot \mathrm{kg}^{-1}$, suggesting a wide range of crop $\mathrm{N}$ status among fields.

Petiole $\mathrm{NO}_{3}-\mathrm{N}$ concentration showed a more rapid decline through the season [Fig. 3; Petiole $\mathrm{NO}_{3}-\mathrm{N}=14.8-(0.017 \times$
GDD), $r=0.82, P<0.001]$. Initial values (3 WAT) ranged from 6 to $18 \mathrm{~g} \cdot \mathrm{kg}^{-1}$, with 11 WAT values $<2 \mathrm{~g} \cdot \mathrm{kg}^{-1}$ in most fields. The majority of petiole samples in both years fell below the $\mathrm{NO}_{3}-\mathrm{N}$ sufficiency level suggested by Lorenz and Tyler (1983). However, the validity of that standard appeared questionable, as Hartz and Bottoms (2009) reported that even high-yield conventional fields had lower petiole $\mathrm{NO}_{3}-\mathrm{N}$ at full bloom and beyond. Compared with the conventional field

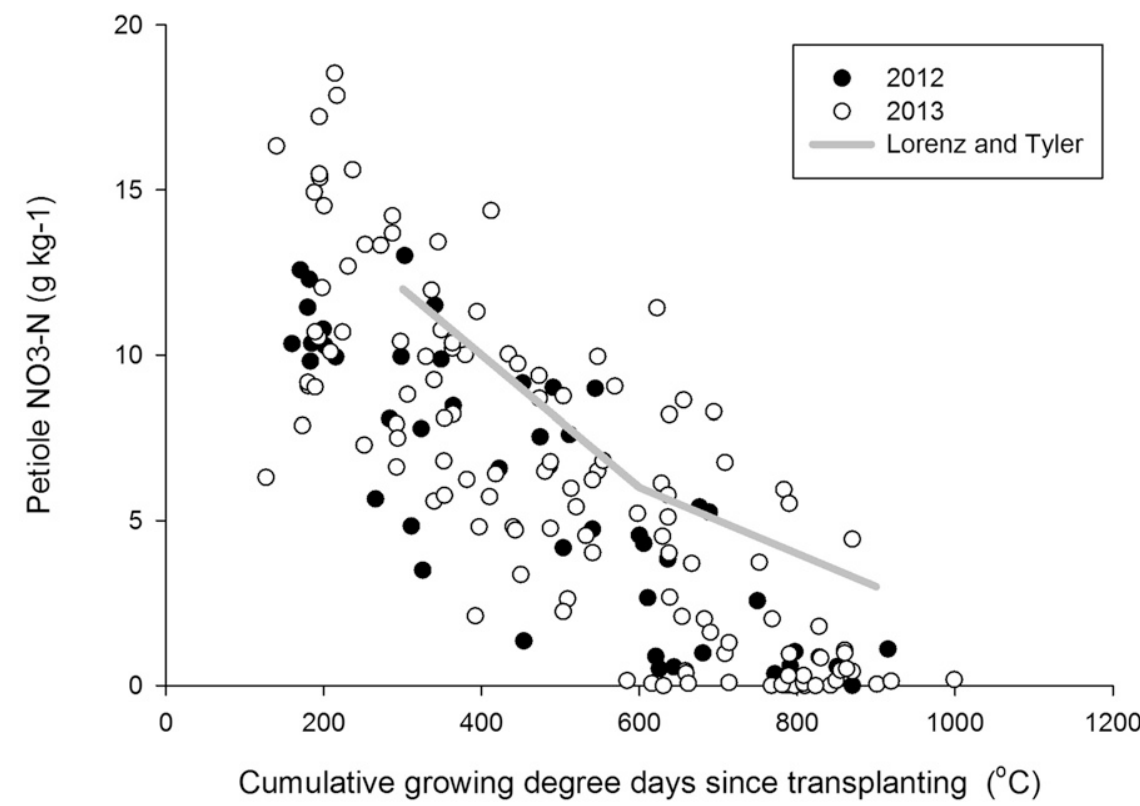

Fig. 3. Trends in petiole $\mathrm{NO}_{3}-\mathrm{N}$ concentration in 37 fields produced during the $2012(\bullet)$ and $2013(\bigcirc)$ growing seasons; 300,600 , and 900 growing degree days corresponded to early bloom, full bloom and early red fruit growth stages. $\mathrm{NO}_{3}-\mathrm{N}$ sufficiency standards proposed by Lorenz and Tyler (1983; gray line).

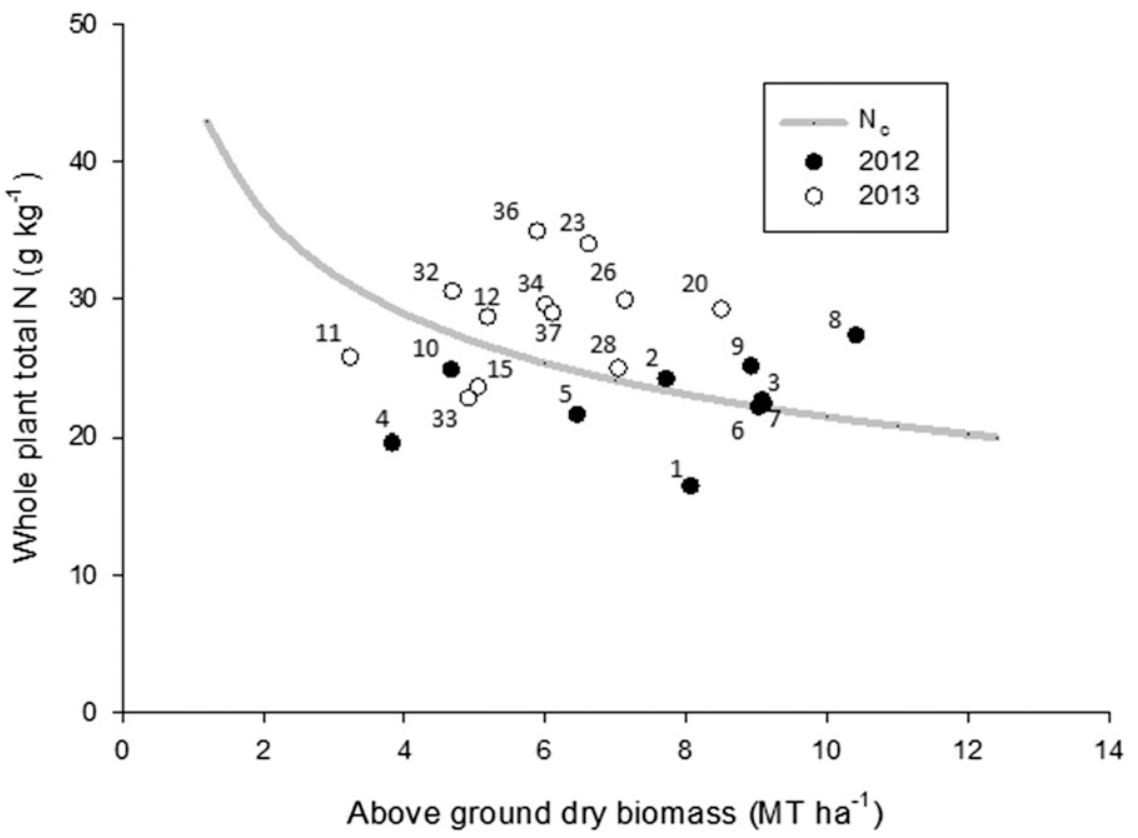

Fig. 4. Whole plant total $\mathrm{N}$ concentration at $\approx 11$ weeks after transplanting (WAT) in 22 fields sampled during the $2012(\bullet)$ and $2013(\bigcirc)$ growing seasons; whole plant critical $\mathrm{N}$ concentration $\left(\mathrm{N}_{\mathrm{c}}\right)$ from Tei et al. (2002, gray line). 
data reported by Hartz and Bottoms (2009), a number of these organic fields showed much steeper decline in petiole $\mathrm{NO}_{3}-\mathrm{N}$, dropping below $5 \mathrm{~g} \cdot \mathrm{kg}^{-1}$ earlier in the season.

Eight of the 22 fields in which 11 WAT plant biomass samples were collected had whole plant $\mathrm{N}$ concentration below $\mathrm{N}_{\mathrm{c}}$, suggesting $\mathrm{N}$ deficiency (Fig. 4). $\mathrm{N}_{\mathrm{c}}$ declines over time, as older leaves senesce and fruit constitutes a larger fraction of plant biomass; therefore, $\mathrm{N}_{\mathrm{c}}$ is expressed as a function of aboveground dry biomass. Fields 1, 4, 5, 6, $10,11,15$, and 33 were those presumed to be $\mathrm{N}$-deficient. Marketable fruit yield in these fields averaged only $66 \mathrm{t} \cdot \mathrm{ha}^{-1}$, whereas the fields of assumed $\mathrm{N}$ sufficiency (those with whole plant $\mathrm{N}$ greater than $\mathrm{N}_{\mathrm{c}}$ ) averaged $89 \mathrm{t} \cdot \mathrm{ha}^{-1}$. Biomass $\mathrm{N}$ at $11 \mathrm{WAT}$ averaged $122 \mathrm{~kg} \cdot \mathrm{ha}^{-1}$ in $\mathrm{N}$-deficient fields compared with $200 \mathrm{~kg} \cdot \mathrm{ha}^{-1}$ in the N-sufficient fields.

Sensitivity analysis (Pannell, 1997) was conducted to determine the accuracy of earlyseason soil or plant monitoring in predicting the development of $\mathrm{N}$ deficiency later in the season. Two criteria were used to assess $\mathrm{N}$ deficiency: leaf $\mathrm{N}$ at 11 WAT below the sufficiency level of Lorenz and Tyler (1983), or whole plant $\mathrm{N}$ concentration at
11 WAT below $\mathrm{N}_{\mathrm{c}}$ (Tei et al., 2002). In this analysis, classification of a field at or above a specified level of the early-season monitoring variable that was subsequently diagnosed as $\mathrm{N}$ sufficient was considered an accurate diagnosis. Similarly, fields below the early monitoring threshold that became $\mathrm{N}$ deficient were accurate diagnoses. Fields at or above a specified level of the early monitoring variable that were later diagnosed as N-deficient were classified as "false positive." Conversely, fields below the specified level of the early-season monitoring variable that were later diagnosed as N-sufficient were classified as "false negative."

SMN at 3 WAT showed promise as a predictor of late season $\mathrm{N}$ deficiency (Fig. 5). SMN correctly predicted late season plant $\mathrm{N}$ status in $60 \%$ to $80 \%$ of fields. Fields below $10-15 \mathrm{mg} \cdot \mathrm{kg}^{-1}$ (whether measured at $0-30$ or 0-60 cm) were likely to become $\mathrm{N}$ deficient, whereas those above this range were likely to remain $\mathrm{N}$ sufficient. As a practical matter, using the higher end of this range would be agronomically justified, as it would lessen the likelihood of classifying a field as $\mathrm{N}$ sufficient when in fact it would become $\mathrm{N}$-deficient (a false positive diagnosis).
Similarly, leaf $\mathrm{N}$ at 5 WAT between 42 and $50 \mathrm{~g} \cdot \mathrm{kg}^{-1}$ correctly predicted late season plant $\mathrm{N}$ status in $\approx 70 \%$ of fields (Fig. 6). Using the upper end of that range (48-50 $\mathrm{g} \cdot \mathrm{kg}^{-1}$ ) as an action threshold would minimize the false positive risk. Petiole $\mathrm{NO}_{3}-\mathrm{N}$ at 5 WAT was a less useful diagnostic. Use of a $9 \mathrm{~g} \cdot \mathrm{kg}^{-1}$ threshold appeared to be a reasonable compromise between overall diagnostic accuracy and false positive minimization.

Sidedress $N$ trials. The fields in which replicated sidedress $\mathrm{N}$ trials were conducted varied in pre-sidedress SMN from 15 to 17 $\mathrm{mg} \cdot \mathrm{kg}^{-1}(0-30 \mathrm{~cm})$ and 11 to $20 \mathrm{mg} \cdot \mathrm{kg}^{-1}(0-60$ $\mathrm{cm}$, Table 2). In all fields, $\mathrm{N}$ application significantly increased leaf $\mathrm{N} \approx 4$ weeks after sidedressing, whereas petiole $\mathrm{NO}_{3}-\mathrm{N}$ was significantly increased in two of the four fields. This confirmed that feather meal mineralized rapidly, as reported by Hartz and Johnstone (2006a). Total fruit yield was significantly increased with sidedress $\mathrm{N}$ by $8 \%$ and $14 \%$ in field 16 and at RR, respectively. No yield response to $\mathrm{N}$ sidedressing was observed in the other fields. In the responsive fields, marketable yield was increased by about the same percentages, but withintreatment variability in cull percentage reduced
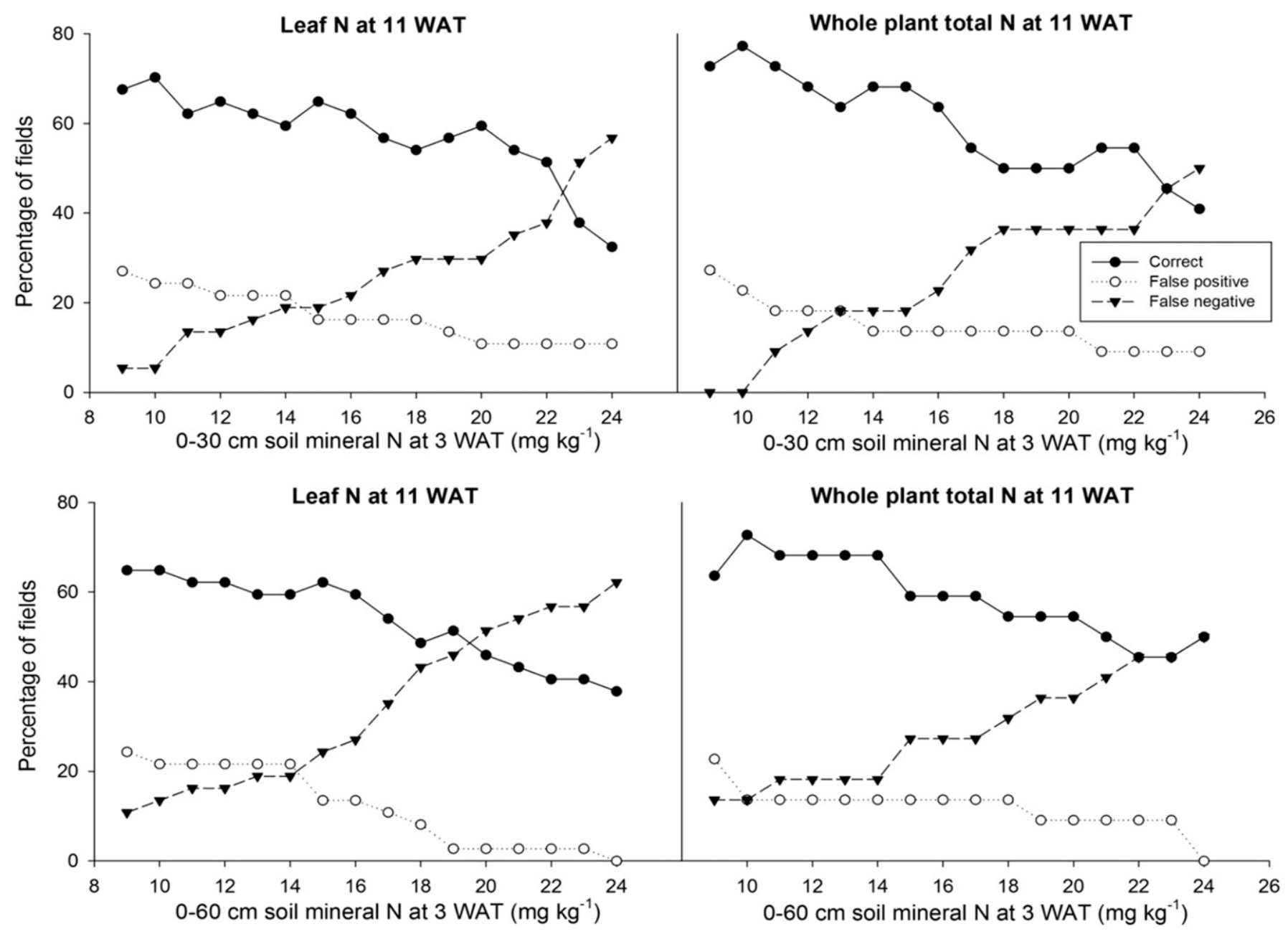

Fig. 5. Sensitivity analysis of 3-week after transplanting (WAT) soil mineral N (0-30 or 0-60 cm depth), comparing various threshold values as predictors of lateseason $\mathrm{N}$ deficiency, as evaluated by comparison of 11 WAT leaf $\mathrm{N}$ with proposed sufficiency standards (Lorenz and Tyler, 1983) or by comparison of 11 WAT whole plant $\mathrm{N}$ concentration with proposed whole plant critical $\mathrm{N}$ concentration (Tei et al., 2002). 

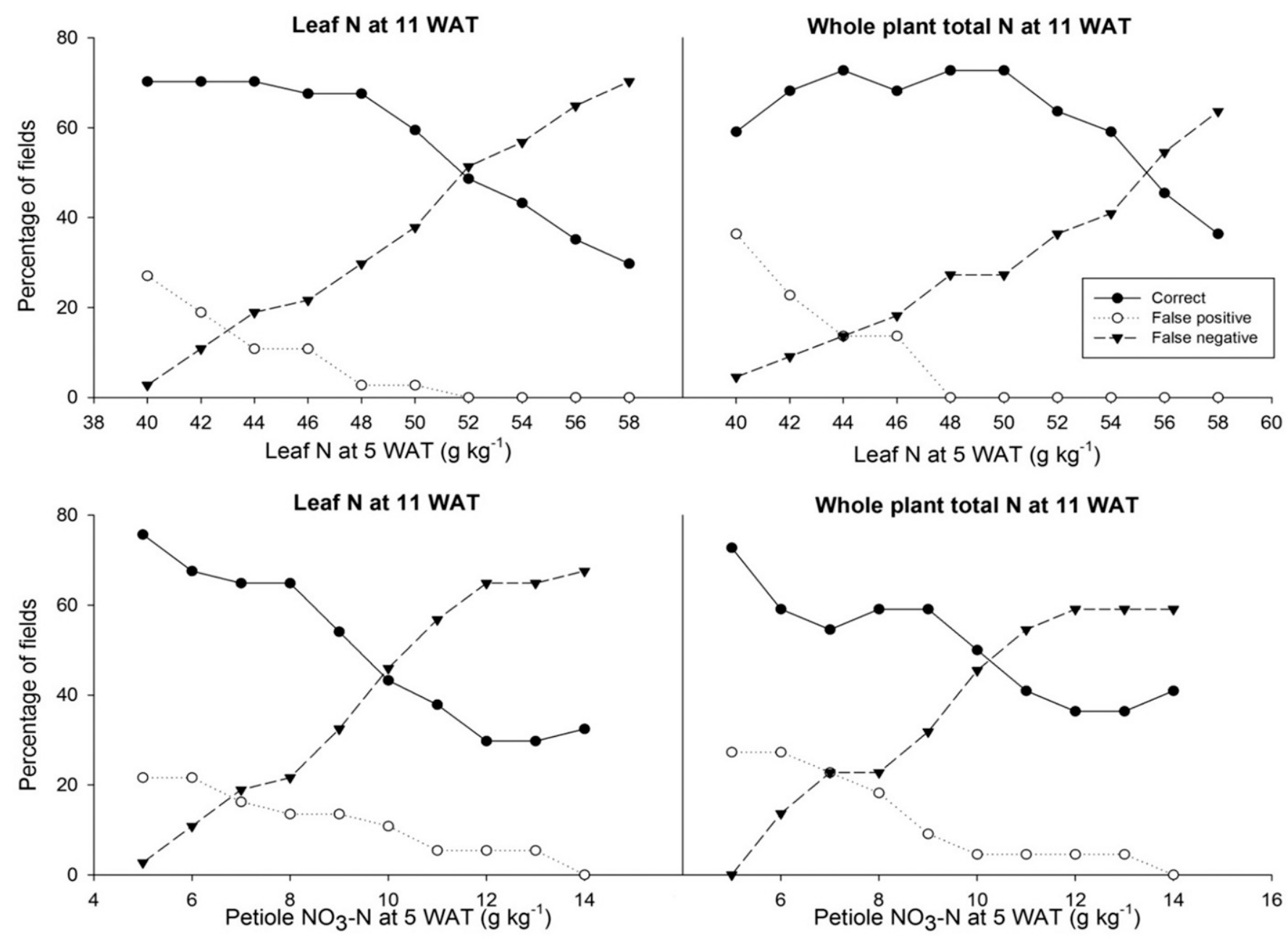

Fig. 6. Sensitivity analysis of 5-week after transplanting (WAT) leaf $\mathrm{N}$ or petiole $\mathrm{NO}_{3}-\mathrm{N}$, comparing various threshold values as predictors of late-season $\mathrm{N}$ deficiency, as evaluated by comparison of 11 WAT leaf $\mathrm{N}$ with proposed sufficiency standards (Lorenz and Tyler, 1983) or by comparison of 11 WAT whole plant $\mathrm{N}$ concentration with proposed whole plant critical $\mathrm{N}$ concentration (Tei et al., 2002).

Table 2. Effects of nitrogen sidedressing on organic processing tomato fruit yield and crop $\mathrm{N}$ status.

\begin{tabular}{|c|c|c|c|c|c|c|c|c|c|c|c|}
\hline \multirow{2}{*}{ Field } & \multirow{2}{*}{ Soil texture } & \multirow{2}{*}{$\begin{array}{c}\text { Organic } \\
\text { matter }\left(\mathrm{g} \cdot \mathrm{kg}^{-1}\right)\end{array}$} & & & \multicolumn{2}{|c|}{ Pre-sidedress } & & \multicolumn{2}{|c|}{ Post-sidedress } & \multirow{2}{*}{\multicolumn{2}{|c|}{ Fruit yield $\left(\mathrm{t} \cdot \mathrm{ha}^{-1}\right)$}} \\
\hline & & & \multicolumn{2}{|c|}{$\mathrm{SMN}\left(\mathrm{mg} \cdot \mathrm{kg}^{-1}\right)$} & N Leaf & Petiole & & N Leaf & Petiole & & \\
\hline$\overline{\mathrm{RR}}$ & Clay loam & 19 & 17 & 11 & 50 & 9.8 & No N & $33 b^{z}$ & $1.3 \mathrm{a}$ & $101.2 \mathrm{~b}$ & $92.9 \mathrm{a}$ \\
\hline - & - & - & - & - & - & - & Sidedress N & $43 \mathrm{a}$ & $6.9 \mathrm{a}$ & $105.2 \mathrm{a}$ & $88.7 \mathrm{a}$ \\
\hline 16 & Clay & 30 & 17 & 13 & 48 & 5.9 & No $\mathrm{N}$ & $41 \mathrm{~b}$ & $1.5 \mathrm{~b}$ & $107.6 \mathrm{~b}$ & $97.1 \mathrm{a}$ \\
\hline - & - & - & - & - & - & - & Sidedress N & $47 \mathrm{a}$ & $4.4 \mathrm{a}$ & $123.1 \mathrm{a}$ & $109.9 \mathrm{a}$ \\
\hline
\end{tabular}

${ }^{\mathrm{z}}$ Mean separation within columns and field trials by Tukey's standardized range test, $P<0.05$.

y Marketable (intact red fruit).

the statistical significance of the treatment differences $(P=0.12$ and 0.11 in field 16 and at RR, respectively). N sidedressing did not affect fruit soluble solids at any site.

Applying the $10-15 \mathrm{mg} \cdot \mathrm{kg}^{-1}$, SMN threshold suggested by the sensitivity analysis on the 0-30 cm soil depth, none of these fields would have been expected to be responsive to sidedress N. However, based on 0-60 cm SMN, three of the four fields may have been responsive, including both sites at which total fruit yield increased. These results suggested that while $0-30 \mathrm{~cm} \mathrm{SMN}$ and 0-60 SMN were highly correlated $(r=0.87, P<0.01), 0-60 \mathrm{~cm}$ measurement provided a more comprehensive evaluation of soil $\mathrm{N}$ supply. Three fields, including both responsive fields, were at the upper end of the leaf $\mathrm{N}$ threshold range suggested by the sensitivity analysis. Although both responsive fields had lower petiole $\mathrm{NO}_{3}-\mathrm{N}$ than the nonresponsive fields, only field 16 was lower than the proposed 9 $\mathrm{g} \cdot \mathrm{kg}^{-1}$ sensitivity analysis threshold.

Soil $N_{\text {min }}$. Net $\mathrm{N}_{\min }$ in $28 \mathrm{~d}$ of incubation ranged from 8 to $31 \mathrm{mg} \cdot \mathrm{kg}^{-1}$, averaging 22 $\mathrm{mg} \cdot \mathrm{kg}^{-1}$. On the basis of the longer term $(70 \mathrm{~d})$ incubation performed on 2013 soils a logarithmic function best described $\mathrm{N}_{\text {min }}$ over time $\left[\mathrm{N}_{\min }\left(\mathrm{mg} \cdot \mathrm{kg}^{-1}\right)=4.643 \ln\right.$ (days) $+5.628, R^{2}=$ $0.29, P=0.0002) . \mathrm{N}_{\min }$ increased between 28 and $70 \mathrm{~d}$ of incubation by only $13 \%$ on average. Net $\mathrm{N}_{\min }$ in $28 \mathrm{~d}$ represented an average of $\sim 2 \%$ of total soil $\mathrm{N}$, similar to prior studies on California soils in annual crop rotations (Hartz et al., 2000; Krusekopf et al., 2002).

Carbon mineralization, WEON and WEOC ranged between 20 and $47 \mathrm{mg} \cdot \mathrm{kg}^{-1}$ $\mathrm{C}, 5$ and $21 \mathrm{mg} \cdot \mathrm{kg}^{-1} \mathrm{~N}$, and 131 and 428 
$\mathrm{mg} \cdot \mathrm{kg}^{-1} \mathrm{C}$, respectively. Correlation of $\mathrm{N}_{\text {min }}$ to $\mathrm{C}_{\min }$ was weak $(r=0.44, P=0.051$, Table 3). Stronger correlations were observed between $\mathrm{N}_{\text {min }}$ and WEOC, WEON, and total soil $\mathrm{N}$ as $r=0.63,0.61$, and 0.51 , respectively, (all $P<0.03$ ). Soil mineral $\mathrm{N}$ at 3 WAT was also correlated with $\mathrm{N}_{\min }(r=$ 0.56 and 0.54 in the $0-30$ and $0-60 \mathrm{~cm}$ depths, respectively). Stepwise (backward) regression analysis using the five independent variables most highly correlated with $\mathrm{N}_{\text {min }}$ (total soil N, SMN: 0-30 cm, SMN: 0-60 cm, WEON and WEOC) showed that a two variable model $\left[\mathrm{N}_{\min }=7.659+0.303\right.$ (SMN: 0-30 cm) + $0.629($ WEON)] dramatically improved prediction of $\mathrm{N}_{\min }\left(\right.$ adj. $R^{2}=$ 0.67, $P<0.001$, Fig. 7).

Table 3. Correlation $(r)$ of soil characteristics with soil $\mathrm{N}$ mineralization potential, as estimated by a $28 \mathrm{~d}$ aerobic incubation at $25^{\circ} \mathrm{C}$.

\begin{tabular}{lcc}
\hline Soil variable & $r$ & $P$ value \\
\hline Soil OM & 0.25 & 0.283 \\
Soil total N & 0.51 & 0.023 \\
Soil total C & 0.40 & 0.077 \\
Dry soil C:N & 0.01 & 0.965 \\
SMN $(0-30 \mathrm{~cm})$ & 0.56 & 0.010 \\
SMN $(0-60 \mathrm{~cm})$ & 0.54 & 0.014 \\
$\mathrm{C}_{\text {min }}$ y & 0.44 & 0.051 \\
WEON $^{\mathrm{x}}$ & 0.61 & 0.004 \\
WEOC $^{\mathrm{w}}$ & 0.63 & 0.003 \\
Water extractable organic C:N $^{\mathrm{N}}$ & -0.15 & 0.526 \\
\hline
\end{tabular}

${ }^{\mathrm{z}}$ Soil mineral $\mathrm{N}$ at 3 weeks after transplanting.

${ }^{\mathrm{y}}$ Carbon mineralization in $24 \mathrm{~h}$ following rewetting

of air-dried soil.

${ }^{x}$ Water extractable organic nitrogen.

${ }^{\mathrm{w}}$ Water extractable organic carbon.

\section{Discussion}

Providing sufficient available soil $\mathrm{N}$ to achieve maximum crop productivity is a challenge in organic production systems. A cornerstone of organic $\mathrm{N}$ management is the use of legume cover crops (Gaskell et al., 2011; Gosling and Ryans, 2005). However, in this study, the use of cover crops was uncommon (only one of the 37 fields monitored had a cover crop preceding tomato planting). Cover cropping in this production system presents logistical hurdles; primarily, the inability in wet years to incorporate cover crop biomass in a timely manner to allow relatively early spring tomato planting. Since the contract with the tomato-processing company specifies harvest timing, growers do not have the luxury of delaying spring planting to make cover cropping more practical.

In lieu of cover cropping, these growers used the application of manure, compost, and organic fertilizers to provide $\mathrm{N}$ fertility. The cooperating growers clearly differed in their use of these materials, as suggested both by the management records provided, and by the wide range of soil $\mathrm{P}$ availability among fields. Manures have relatively high P:N ratios, and reliance on such products to supply $\mathrm{N}$ results in soil P buildup (Daniel et al., 1994; MaltaisLandry et al., 2015). Fields ranged from 4 to $98 \mathrm{mg} \cdot \mathrm{kg}^{-1}$ bicarbonate extractable $\mathrm{P}$, averaging $39 \mathrm{mg} \cdot \mathrm{kg}^{-1}$. For context, Hartz et al. (1998) reported that the mean soil extractable P level of conventionallymanaged California processing tomato fields was $18 \mathrm{mg} \cdot \mathrm{kg}^{-1}$.

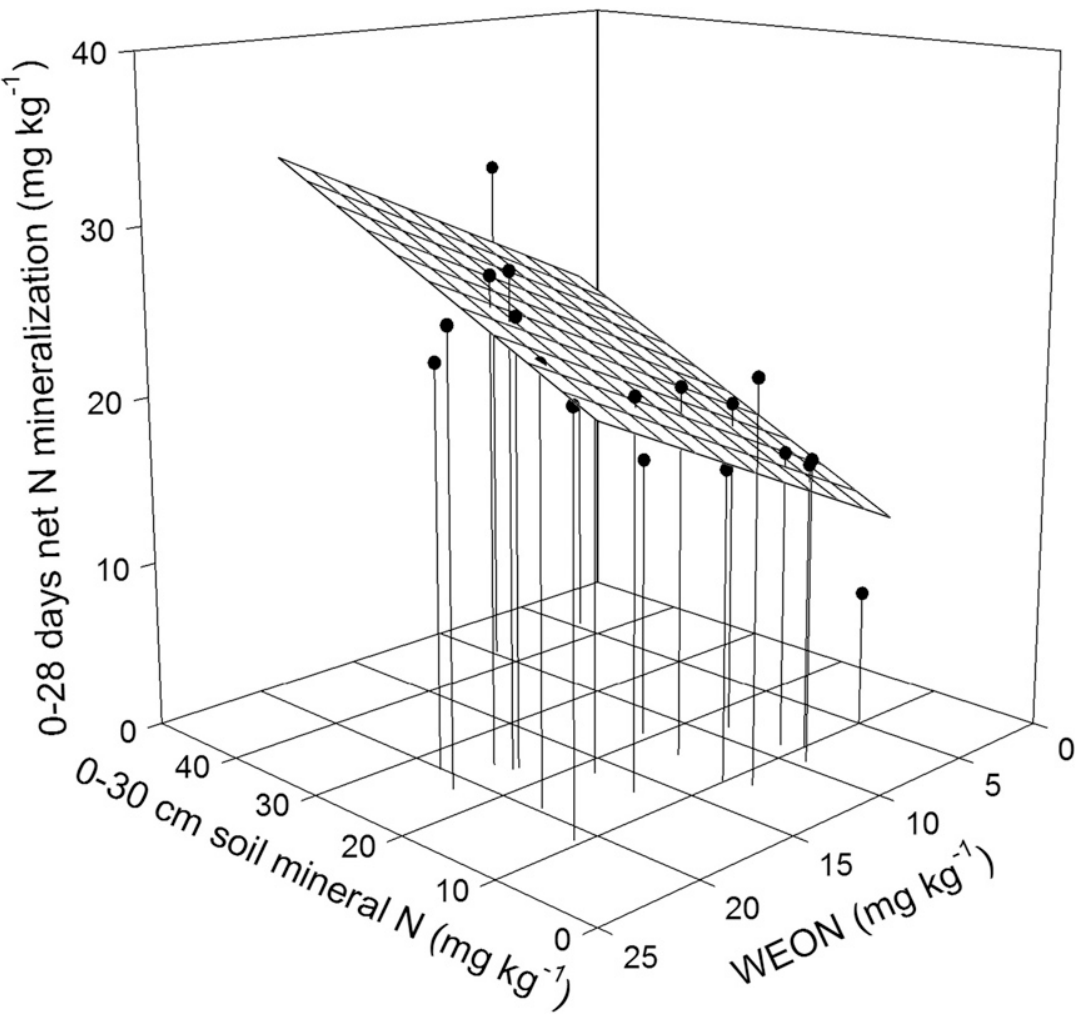

Fig. 7. Observed (•) and predicted (plane) values of $0-28 \mathrm{~d}$ net $\mathrm{N}$ mineralization $\left(\mathrm{mg} \cdot \mathrm{kg}^{-1}\right.$ ) from a multiple linear regression model using $0-30 \mathrm{~cm}$ soil mineral $\mathrm{N}\left(\mathrm{X}_{1}, \mathrm{mg} \cdot \mathrm{kg}^{-1}\right)$ and water extractable organic $\mathrm{N}$ (WEON, $\left.\mathrm{X}_{2}, \mathrm{mg} \cdot \mathrm{kg}^{-1}\right)$ as independent variables $\left(\mathrm{Y}=0.303 \times \mathrm{X}_{1}+0.629 \times \mathrm{X}_{2}+7.659\right)$.
This soil $\mathrm{P}$ buildup in organic culture has potential environmental implications, as winter surface runoff from Sacramento Valley fields is common, and soil P level is strongly predictive of $\mathrm{P}$ concentration in runoff (Hartz and Johnstone, 2006b).

Processing tomato is a high-N demand crop. Hartz and Bottoms (2009) reported that for high-yielding drip-irrigated tomato fields (mean fruit yield of $143 \mathrm{Mg} \cdot \mathrm{ha}^{-1}$ ) the mean critical $\mathrm{N}$ uptake requirement $\left(\mathrm{N}_{\text {upt }}\right.$, the $\mathrm{N}$ uptake required to maintain whole plant $\mathrm{N}$ above $\mathrm{N}_{\mathrm{c}}$ and therefore nonlimiting to growth) averaged $\approx 260 \mathrm{~kg} \cdot \mathrm{ha}^{-1}$. At a realistic yield goal for furrow-irrigated organic processing tomato fields (100-120 Mg.ha ${ }^{-1}$, based on the high-yielding fields in this study), $\mathrm{N}_{\text {upt }}$ would be proportionally lower, in the range of $180-220 \mathrm{~kg} \cdot \mathrm{ha}^{-1}$. That estimate matched the biomass $\mathrm{N}$ uptake observed in fields deemed $\mathrm{N}$-sufficient, which averaged $200 \mathrm{~kg} \cdot \mathrm{ha}^{-1}$ by $11 \mathrm{WAT}$.

In this study, SMN $(0-60 \mathrm{~cm})$ at 3 WAT ranged from 6 to $32 \mathrm{mg} \cdot \mathrm{kg}^{-1}$. At a typical soil bulk density of $1.35 \mathrm{~g} \cdot \mathrm{cm}^{3}$, each $\mathrm{mg} \cdot \mathrm{kg}^{-1}$ $\mathrm{SMN}$ represented $\approx 8 \mathrm{~kg} \cdot \mathrm{ha}^{-1} \mathrm{~N}$ in the top $60 \mathrm{~cm}$ of soil. Therefore the observed SMN range was $\approx 50-260 \mathrm{~kg} \cdot \mathrm{ha}^{-1}$, with a mean of $130 \mathrm{~kg} \cdot \mathrm{ha}^{-1}$. Soil $\mathrm{N}_{\min }$ potential represented a similar amount of $\mathrm{N}$ supply. $\mathrm{N}_{\text {min }}$ ranged from 8 to $31 \mathrm{mg} \cdot \mathrm{kg}^{-1}$, or $\approx 30-120 \mathrm{~kg} \mathrm{~N} / \mathrm{ha}$ in the top $30 \mathrm{~cm}$ of soil in $28 \mathrm{~d}$, and marginally higher in $70 \mathrm{~d}$. While in the field the majority of $\mathrm{N}_{\text {min }}$ occurs in the top $30 \mathrm{~cm}$ of soil (Cassman and Munns, 1980; Hadas et al., 1986), substantial $\mathrm{N}_{\min }$ can occur below that depth, suggesting that in-field $\mathrm{N}_{\min }$ over a production season may be still higher.

These calculations highlight several important points about organic $\mathrm{N}$ management. First, residual SMN was clearly important in determining the adequacy of soil $\mathrm{N}$ supply because in most fields SMN represented $>50 \%$ of crop $\mathrm{N}$ requirement, and in some fields SMN alone was adequate to support the entire crop, absent leaching by irrigation. Second, these fields differed substantially in soil $\mathrm{N}_{\min }$ potential, and practical laboratory tests that accurately rank this potential could be useful in predicting $\mathrm{N}$ sidedressing requirements in fields with low to intermediate $\mathrm{SMN}$. Unfortunately, we found $\mathrm{C}_{\min }$, WEON, and WEOC to be less strongly correlated to $\mathrm{N}_{\min }$ than did Haney et al. (2001, 2008b, 2012). However, the combination of WEON and SMN $(0-30 \mathrm{~cm})$ was highly predictive of $\mathrm{N}_{\min }$, and appeared to provide timely and practical guidance. The relationship between $\mathrm{N}_{\min }$ and SMN may be unique to semiarid areas such as the Sacramento Valley in which $\mathrm{NO}_{3}-\mathrm{N}$ leaching by rainfall is limited, and it could be confounded by seasonal or management effects.

In this study, sensitivity analysis suggested an action threshold range of 10-15 $\mathrm{mg} \cdot \mathrm{kg}^{-1}$ for post-transplanting SMN; without $\mathrm{N}$ sidedressing, $\mathrm{N}$ deficiency was likely to develop in fields below this range, and unlikely in fields above it. This finding agreed with Krusekopf et al. (2002). Working in conventionally farmed California tomato 
fields, they found that only 4 of 10 fields were responsive to $\mathrm{N}$ sidedressing, all with posttransplanting SMN $<16 \mathrm{mg} \cdot \mathrm{kg}^{-1}$. They also reported that SMN varied from 4 to 29 $\mathrm{mg} \cdot \mathrm{kg}^{-1}$, similar to the range observed in these organic fields.

The similarity of the results of Krusekopf et al. (2002) with those of this study suggests that $\mathrm{N}$ dynamics in organic production are not radically different from in conventional production. In both systems, residual SMN plays a significant role in crop fertility. Organically managed soils, by virtue of higher organic $\mathrm{N}$ content, may have somewhat higher $\mathrm{N}_{\min }$ potential. However, in neither system does $\mathrm{N}_{\text {min }}$ keep pace with crop $\mathrm{N}$ uptake during the peak uptake phase of the season. This was demonstrated by the substantial decline in SMN over the season in all organic fields. Furthermore, leaf $\mathrm{N}$ and $\mathrm{N}_{\mathrm{c}}$ diagnostic criteria developed for conventional production appeared to be applicable to organic production.

Obtaining a fruit yield response to $\mathrm{N}$ sidedressing as late as 5-6 WAT (as occurred in the $\mathrm{N}$ trials) confirmed that early-season soil and plant monitoring can be practical $\mathrm{N}$ management tools. Because $>60 \%$ of the $\mathrm{N}$ in high-N fertilizers such as feather meal can mineralize within 4 weeks at summer soil temperature (Hartz and Johnstone, 2006a), a relatively high $\mathrm{N}$ uptake efficiency should be possible, as was suggested by the significantly enhanced crop $\mathrm{N}$ status documented in the sidedress $\mathrm{N}$ trials. SMN sampling earlier than 3 WAT would give a grower more time to respond to the test result, but may require a lower action threshold. Tissue sampling earlier than 4-5 WAT would be of questionable value, given the slow growth rate in the initial WAT, and potential carryover effects of the initial $\mathrm{N}$ status of the transplants, which can vary considerably (Hartz et al., 2002).

There is a level of inaccuracy inherent in predicting seasonal $\mathrm{N}$ sufficiency from earlyseason monitoring because factors other than soil $\mathrm{N}$ supply can affect crop $\mathrm{N}$ status. In particular, excessive irrigation could result in nitrate leaching, and inadequate irrigation could restrict root development. Weed competition, a serious problem in some organic fields, could also limit crop $\mathrm{N}$ uptake. These (or other) management factors may have been responsible for some of the false positive results of the sensitivity analysis.

Given the high value of organic processing tomatoes (in recent years $>\$ 100$ per $\mathrm{Mg}$ ), sidedressing an organic fertilizer such as feather meal can be a profitable practice despite the high cost of this material (currently about $\$ 8$ per $\mathrm{kg} \mathrm{N}$ ). Sidedressing 30 $35 \mathrm{~kg} \cdot \mathrm{ha}^{-1} \mathrm{~N}$ increased total fruit yield by 8 and $16 \mathrm{Mg} \cdot \mathrm{ha}^{-1}$ in the responsive fields, which represented a clear economic benefit. The fact that only $30 \%$ of fields became $\mathrm{N}$ deficient highlights the importance of being able to accurately identify fields potentially responsive to in-season $\mathrm{N}$ fertilization.

The results of this study have implications for the organic production of other high-N demand vegetable crops. Because in-season soil $\mathrm{N}_{\min }$ appears unlikely to keep pace with crop $\mathrm{N}$ uptake, fields that do not begin the season with substantial SMN are at greater risk of developing yield-limiting $\mathrm{N}$ deficiency. Although SMN and leaf $\mathrm{N}$ action thresholds may be crop and production area specific, we hypothesize that early-season soil and plant $\mathrm{N}$ monitoring could provide practical guidance to in-season $\mathrm{N}$ management across a range of organically produced crops. Laboratory proxy measurement of soil $\mathrm{N}_{\text {min }}$ such as WEON may be a useful adjunct to soil and plant testing.

\section{Literature Cited}

Allen, J.C. 1976. A modified sine wave method for calculating degree-days. Environ. Entomol. 5:388-396.

Berry, P.M., R. Sylvester-Bradley, L. Philipps, D.J. Hatch, S.P. Cuttle, F.W. Ryans, and P. Gosling. 2002. Is the productivity of organic farms restricted by the supply of available nitrogen? Soil Use Mgt. 18:248-255.

Bhogal, A., M.A. Shepherd, D.J. Hatch, L. Brown, and S.C. Jarvis. 2001. Evaluation of two N cycle models for the prediction of $\mathrm{N}$ mineralization from grassland soils in the UK. Soil Use Mgt. 17:163-172.

Cassman, K.G. and D.N. Munns. 1980. Nitrogen mineralization as affected by soil moisture, temperature and depth. Soil Sci. Soc. Amer. J. 44:1233-1237.

Breschini, S.J. and T.K. Hartz. 2002. Presidedress soil nitrate testing reduces nitrogen fertilizer use and nitrate leaching hazard in lettuce production. HortScience 37:1061-1064.

Daniel, T.C., A.N. Sharpley, D.R. Edwards, R. Wedepohl, and J.L. Lemunyon. 1994. Minimizing surface water eutrophication from agriculture by phosphorus management. J. Soil Water Conserv. 49:30-38.

Doane, T.A. and W.R. Horwath. 2003. Spectrophotometric determination of nitrate with a single reagent. Anal. Lett. 36:2713-2722.

Forster, J.C. 1995. Soil nitrogen, p. 79-87. In: K. Alef and P. Nannipieri (eds.). Methods in applied soil microbiology and biochemistry. Academic Press, San Diego, CA.

Fox, R.H., G.W. Roth, K.V. Iversen, and W.P. Piekielek. 1989. Soil and tissue nitrate tests compared for predicting soil nitrogen availability to corn. Agron. J. 81:971-974.

Gaskell, M. and R. Smith. 2007. Nitrogen sources for organic vegetable crops. HortTechnology $17: 431-441$.

Gaskell, M., R.F. Smith, J. Mitchell, S.T. Koike, C. Fouche, T.K. Hartz, W. Horwarth, and L. Jackson. 2011. Soil fertility management for organic crops, p. 29-38. In: M.E. McGiffen, Jr. (ed.). Organic vegetable production manual. University of California. Publication 3509.

Gill, K., S.C. Jarvis, and D.J. Hatch. 1995. Mineralization of nitrogen in long-term pasture soils: Effects of management. Plant Soil 172:153-162.

Gosling, P. and F. Ryans. 2005. Fertility building, p. 67-98. In: G. Davis and M. Lennartsson (eds.). Organic vegetable production a complete Guide. 1st ed. Crowood Press, Wiltshire, UK.

Hadas, A., S. Feigenbaum, A. Feigin, and R. Portnoy. 1986. Nitrogen mineralization in profiles of differently managed soil types. Soil Sci. Soc. Amer. J. 50:314-319.

Haney, R.L., F.M. Hons, M.A. Sanderson, and A.J. Franzluebbers. 2001. A rapid procedure for estimating nitrogen mineralization in manured soil. Biol. Fertil. Soils 33:100-104.

Haney, R.L., W.F. Briton, and E. Evans. 2008a. Soil $\mathrm{CO}_{2}$ respiration: Comparison of chemical titration, $\mathrm{CO}_{2}$ IRGA analysis and solvita gel system. Renew. Agric. Food Syst. 23:171-176.

Haney, R.L., W.F. Briton, and E. Evans. 2008 b. Estimating soil carbon, nitrogen and phosphorus mineralization from short-term carbon dioxide respiration. Commun. Soil Sci. Plant Anal. 39:2706-2720.

Haney, R.L. and E.B. Haney. 2010. Simple and rapid laboratory method for rewetting dry soil for incubations. Commun. Soil Sci. Plant Anal. 4:1493-1501.

Haney, R.L., A.J. Franzluebbers, V.L. Jin, M. Johnson, E.B. Haney, M.J. White, and R.D. Harmel. 2012. Soil organic C:N vs waterextractable organic C:N. Open J. Soil Sci. 2: 269-274.

Hartz, T.K., E.M. Miyao, and J.G. Valencia. 1998. DRIS evaluation of the nutritional status of processing tomato. HortScience 33:830-832.

Hartz, T.K., W.E. Bendixen, and L. Wierdsma. 2000. The value of presidedress soil nitrate testing as a nitrogen management tool in irrigated vegetable production. HortScience 35:651-656.

Hartz, T.K., C. Giannini, E.M. Miyao, and J.G. Valencia. 2002. Divergent transplant production practices produce comparable growth, yield and quality of processing tomato. HortScience 37:296-299.

Hartz, T.K. and P.R. Johnstone. 2006a. Nitrogen Availability from high nitrogen-containing organic fertilizers. HortTechnology 16:39-42.

Hartz, T.K. and P.R. Johnstone. 2006b. Relationship between soil phosphorus availability and phosphorus loss potential in runoff and drainage. Commun. Soil Sci. Plant Anal. 37:1525-1536.

Hartz, T.K. and T.G. Bottoms. 2009. Nitrogen requirements of drip-irrigated processing tomatoes. HortScience 47:1988-1993.

Hatch, D.J., S.C. Jarvis, and S.E. Reynolds. 1991. An assessment of the contribution of net mineralization to $\mathrm{N}$ cycling in grass swards using a field incubation method. Plant Soil 138:23-32.

Heckman, J.R., W.T. Hlubick, D.J. Prostak, and J.W. Paterson. 1995. Pre-sidedress soil nitrate test for sweetcorn. HortScience 30:1033-1036.

Heckman, J.R., T. Morris, J.B. Sims, U. Sieczka, U. Krogmann, P. Nitzsche, and R. Ashley. 2002. Presidedress soil nitrate test is effective for fall cabagge. HortScience 37:113-117.

Jones, J.B., B. Wolf, and H.A. Mills. 1991. Plant analysis handbook. Macro-Micro Publishing, Athens, GA.

Klonsky, K. 2010. A Look at California's Organic Agriculture Production. ARE update 14(2): 8-11. University of California Giannini Fundation of Agricultural Economics. 10 Sept. 2014. $<$ http://giannini.ucop.edu/media/are-update/ files/articles/v14n2_3.pdf $>$.

Krusekopf, H.H., J.P. Mitchell, T.K. Hartz, D.M May, E.M. Miyao, and M.D. Cahn. 2002. Presidedress soil nitrate testing identifies processing tomato fields not requiring sidedress $\mathrm{N}$ fertilizer. HortScience 37:520-524.

Lorenz, O.A. and K.B. Tyler. 1983. Plant tissue analysis of vegetable crops, p. 24-29. In: H.M. Reisenaur (ed.). Soil and plant tissue testing in California. California Coop. Exten. Bul. 1879.

Maltais-Landry, G., K. Scow, E. Brennan, and P. Vitousek. 2015. Long-term effets of Compost and cover crops on soil phosphorus in two California agroecosystems. Soil Sci. Soc. Amer. J. 79:688-697. 
Muramoto, J., R. Smith, C. Shennan, K. Klonsky, J. Leap, M. Silva Ruiz, and S.R. Gliessman. 2011. Nitrogen contribution of legume/cereal mixed cover crops and organic fertilizers to an organic broccoli crop. HortScience 46: 1154-1162.

Olsen, S.R. and L.E. Sommers. 1982. Phosphorus, p. 403-430. In: A.L. Page, R.H. Miller, and D.R. Keeney (eds.). Methods of soil analysis: Part 2 Chemical and microbiological properties. Monogr. No. 9. Amer. Soc. Agron. Madison, WI

Pannell, D.J. 1997. Sensitivity analysis of normative economic models: Theoretical framework and practical strategies. Agr. Econ. 16:139-152.

Pruitt, W.D., E. Fereres, and R.L. Snyder. 1987. Reference evapotranspiration $\left(\mathrm{ET}_{\mathrm{o}}\right)$ for California. Univ. of Calif. Coop. Ext. Bul. 1922.

Sheldrick, B.H. and C. Wang. 1993. Particle size distribution, p. 499-511. In: M.R. Carter (ed.)
Soil sampling and methods of analysis. Can. Soc. Soil Sci., Lewis Publishers, Ann Arbor, MI.

Storer, D.A. 1984. A simple high sample volume ashing procedure for determination of soil organic matter. Commun. Soil Sci. Plant Anal. 15:759-772.

Tei, F., P. Benincasa, and M. Guiducci. 2002. Critical nitrogen concentration in processing tomato. Eur. J. Agron. 18:45-55. 